\title{
Simulation of a surface spill of different diesel/biodiesel mixtures in an ultisol, using natural attenuation and bioaugmentation/biostimulation
}

\author{
DANIEL D. MEYER ${ }^{1}$, SABRINA A. BEKER ${ }^{1}$, KARINA HECK ${ }^{2}$, MARIA \\ DO CARMO R. PERALBA ${ }^{3}$ and FÁTIMA M. BENTO ${ }^{1}$ Rio Grande do Sul, Rua Sarmento Leite, 500, 90050-170 Porto Alegre, RS, Brazil
${ }^{2}$ Programa de Pós-Graduação em Tecnologias e Inovações Ambientais, Universidade Federal de Lavras, Rua Sylvio Menicucci, 1001, 37200-000 Lavras, MG, Brazil
${ }^{3}$ Universidade Federal do Rio Grande do Sul, Instituto de Química, \\ ${ }^{1}$ Programa de Pós-Graduação em Microbiologia Agrícola e do Ambiente, Universidade Federal do \\ Rua Sarmento Leite, 500, 90050-170 Porto Alegre, RS, Brazil
}

Manuscript received on April 12, 2017; accepted for publication on May 19, 2017

\begin{abstract}
Accidents caused by leaks and/or spills on soils need to be addressed. Natural attenuation, biostimulation and bioaugmentation can be useful bioremediation strategies for decontamination processes in soils of diesel/ biodiesel mixtures. The purpose of this study was to evaluate the degradation rate of the different fuels (B0, B20 and B100) in an ultisol under natural attenuation and biostimulation/bioaugmentation during 60 days of incubation in a controlled microcosm simulating a surface spill over soil. The degradation of different diesel/biodiesel mixtures was monitored for up to 60 days by dehydrogenase activity, respirometry by $\mathrm{CO}_{2}$ release, the most probable number of heterotrophic and degrading microorganism and gas chromatography. The bacterial inoculum employed for biostimulation/bioaugmentation strategy consisted of Bacillus megaterium, Bacillus pumilus, Pseudomonas aeruginosa, and Stenotrophomonas maltophilia. The two bioremediation strategies have showed great degradation rates. The natural attenuation was effective for B0 and B20 treatments. The addition of the bacterial consortium and macronutrients contributed to the increased degradation of pure biodiesel in relation to natural attenuation, with higher rates for $\mathrm{CO}_{2}$ release, enzymatic and degrading activity. It is suggested that the bacterial consortium has proven effective for presenting significant values for such parameters until the end of the 60-day incubation period.
\end{abstract}

Key words: bacterial consortium, bioremediation strategies, dehydrogenase, respirometry, soil spill.

\section{INTRODUCTION}

Biodiesel, for being a fuel from renewable sources and lipid nature, is getting more space in the Brazilian and world energy matrix, as an alternative

Correspondence to: Fátima Menezes Bento

E-mail: fatima.bento@ufrgs.br for diesel replacement (Knothe 2010). In addition, this biofuel has many advantages compared to diesel, such as lower toxicity and higher biodegradation rates. Several countries are already adding biodiesel to diesel, helping to reduce the environmental problems caused by the presence of hydrocarbons (Silva et al. 2012, Brasil 2016). There 
are activities related mainly to the transport and storage of these fuels that may cause accidents such as leaks and/or spills, generating contamination in different environmental compartments (Tahhan et al. 2011).

Adding biodiesel to diesel may contribute to increased degradation of the hydrocarbon fraction, due to the phenomenon of co-metabolism (Fernandez-Alvarez et al. 2007, Gong et al. 2010, Yassine et al. 2013). Some bioremediation strategies can be used in case of accidents with these fuels, highlighting natural attenuation, biostimulation, bioaugmentation and their combinations. Although natural attenuation is one of the cheapest bioremediation strategies, it is not always the most effective. The bioaugmentation and biostimulation, especially their combination, can enhance the diesel and biodiesel degradation in soils (Fantroussi and Agathos 2005, Liu et al. 2009, Xu and Lu 2010, Tyagi et al. 2011, Meyer et al. 2014).

Bioaugmentation is a technique that helps to improve the ability of a contaminated area to remove contaminants by adding an isolated and identified strain or a consortium of potentially degrading microorganisms, evaluated technologically in laboratory conditions. Several researches report the use of consortia rather than a single isolate, since many microorganisms are only able to biotransform a toxic compound into intermediate compounds of the degradation pathway. Thus, the presence and interaction of other species are needed to complete the process, completely converting the organic contaminant into carbon dioxide by respiratory process (Fantroussi and Agathos 2005). The addition of nutrients can also accelerate the fueldegrading process, giving nitrogen and phosphorus to microbial cell replication, optimizing the proliferation of indigenous or exogenous microbial community highly efficient for bioremediation (Tyagi et al. 2011), especially in stable sites with low nutrients ratio.
Many classic parameters such as respirometry techniques, most probable number of heterotrophic and biodegrading plate counts, enzyme activity quantification in soils and gas chromatography, may contribute to assess not only the microbial activity, but also to estimate the degradation rates of different diesel/biodiesel mixtures present in soil under different bioremediation strategies (Silva et al. 2012, Meyer et al. 2014). The purpose of this study was to evaluate the degradation rate for different fuels and mixtures (B0, B20 and $\mathrm{B} 100)$ in an ultisol under two bioremediation strategies (natural attenuation and biostimulation/ bioaugmentation) during 60 days of incubation in a controlled microcosm, simulating a surface spill.

\section{MATERIALS AND METHODS}

\section{SOIL SAMPLES}

Representative surface soil samples were collected from an area without history of contamination at $0-20 \mathrm{~cm}$ depth (Horizon A), classified by the Brazilian Soil Classification System (EMBRAPA 2006) as Typical Red Dystrophic Argisol (ADL), sandstone substrate, being collected in an area next to the BR 386 Federal Highway, geographically located in city of Triunfo, Coxilha Velha area, RS (29 44'09' S, 51 ${ }^{\circ} 37^{\prime} 44,7^{\prime}$ ' W) respectively. After collection, the material was sieved through a $2 \mathrm{~mm}$ mesh screen. Soil moisture was standardized, maintaining field capacity around 60\%. The physicochemical properties of the soils were determined by laboratory analysis, according to the methods described by Tedesco et al. (1995).

FUEL

Metropolitan diesel (B0) and soy methyl biodiesel (B100) samples were used provided by the Ipiranga Petroleum Distributor and BSBios companies, respectively. The fuels used were pure diesel, pure biodiesel and B20 (20\% biodiesel and 80\% diesel) $(\mathrm{V} / \mathrm{V})$. These fuels were added to the soil. The B20 
was previously prepared in the laboratory using a graduated cylinder. The fuels were stored in dark bottles, in order to be protected from light, avoiding photo-oxidation.

\section{SOIL BIOREMEDIATION EXPERIMENTS}

$300 \mathrm{~g}$ of soil were incubated in respirometric flasks (1 L), keeping the rest of the volume for gaseous changes between microcosms and inner atmosphere. The moisture was adjusted and kept to $60 \%$ of field capacity (capability of $60 \%$ soil micropores turn full of water). The deliberate contamination of soils was conducted under experimental design characterized by four different fuel mixtures (control, B0, B20 and B100) and two bioremediation strategies (natural attenuation and bioaugmentation/biostimulation) in triplicate, according factorial scheme $4 \times 2$, totaling twentyfour experimental plots. $9 \mathrm{~mL}$ of fuel were added to moist soil (30 mL. $\mathrm{Kg}^{-1}$, simulating a surface fuel spill on a 0.5 hectare soil by a tank-truck able to charge $30.000 \mathrm{~L}$ of fuel), mixing with a spatula to make the content of each microcosm as homogeneous as possible. The microcosms were assembled according to the following layout: two bioremediation strategies, being natural attenuation and bioaugmentation/biostimulation, and control treatment (without fuel). In order to evaluate the microbial activity during degradation, were performed respirometry experiments, evaluation of dehydrogenase activity and heterotrophic/ degrading bacteria plate count during period of incubation, as well as gas chromatography, to estimate the percentage of fuel that was degraded at the end of incubation. The experiments were performed in triplicate and incubated for a period of 60 days. In order to estimate by the natural attenuation biodegradation activity, it was considered only the indigenous microorganisms in the soil, with no nutrient addition. For the bioaugmentation/biostimulation strategy, an inoculum was added by pipetting and mixed to the soil, consisting of four bacterial isolates at a final concentration of $2.10^{8} \mathrm{UFC}^{-1}$ (modified from Bento et al. 2003): Bacillus megaterium, Bacillus pumilus, Pseudomonas aeruginosa and Stenotrophomonas maltophilia (Meyer et al. 2012), in addition to a nutrient solution of $\mathrm{NH}_{4} \mathrm{NO}_{3}$ and $\mathrm{KH}_{2} \mathrm{PO}_{4}$ at variable concentrations, so that the $\mathrm{C}: \mathrm{N}: \mathrm{P}$ ratio was adjusted to $120: 10: 1$ for each treatment (performing the amount of macronutrient composed and required by the bacterial cell for organic matter degradation), according to the composition of the soil, as suggested by Jiménez et al. (2007). The carbon source provided was exclusively from the fuel.

\section{RESPIRATORY ACTIVITY}

The microbial respiratory activity in closed microcosms containing soil contaminated with diesel and/or biodiesel was evaluated by cumulative liberation of $\mathrm{CO}_{2}$ (Stotzky 1965). A capturing system for $\mathrm{CO}_{2}$ was assembled in each microcosm. The capturing system consisted of a plastic cup containing $20 \mathrm{~mL}$ of $\mathrm{NaOH} 0.75 \mathrm{~mol} . \mathrm{L}^{-1}$ suspended in a metal frame. Flasks without soil were used as blanks in order to quantify the $\mathrm{CO}_{2}$. The flasks were kept tightly closed and only periodically opened for basal respiration determination. The analyses were performed using $3 \mathrm{~mL}$ of $\mathrm{BaCl}_{2} \cdot 2 \mathrm{H}_{2} \mathrm{O} 30 \%$ and 3 drops of phenolphthalein $1 \%$ were added to the $\mathrm{NaOH}$ solution. The residual amount of $\mathrm{NaOH}$ was titrated with $\mathrm{HCl} 0.5$ mol. $\mathrm{L}^{-1}$. The carbonic gas produced was calculated by the equation:

$\mathrm{C}-\mathrm{CO}_{2}$ generated $\left(\mathrm{mg} \cdot \mathrm{Kg}^{-1}\right.$ soil $)=\left(\mathrm{V}_{\mathrm{B}}-\mathrm{V}_{\mathrm{A}}\right)$. $\left(\mathrm{M}_{\mathrm{C}} / 2\right) \cdot M_{\mathrm{HCl}}(\mathrm{FC} / \mathrm{m}) \quad$ Equation 1 where: $V_{B}$ is volume in $\mathrm{mL}$ of $\mathrm{HCl} 0.5$ mol. $\mathrm{L}^{-1}$ used to titrate the blank proof; $V_{A}$ is volume in $\mathrm{mL}$ of $\mathrm{HCl} 0.5 \mathrm{~mol} . \mathrm{L}^{-1}$ used to titrate the treatment; $M_{C}$ is the carbon molar mass in $\mathrm{g} \cdot \mathrm{mol}^{-1} ; M_{\mathrm{HCl}}$ is the concentration in mol. $\mathrm{L}^{-1}$ of the standardized $\mathrm{HCl}$ 
solution; $F C$ is the correction factor for the molarity $\left(M_{\mathrm{HCl}} / M_{\mathrm{NaOH}}\right)$ and $m$ is the mass $(\mathrm{kg})$ of dry soil in the flask.

\section{DEHYDROGENASE ACTIVITY}

The dehydrogenase activity was determined according to the method proposed by Thalmann (1968) and Alef (1995) with modifications. $2 \mathrm{~g}$ of moist soil were collected from every respirometric flasks and added to $2 \mathrm{ml}$ 2,3,5-triphenyl tetrazolium chloride (TTC) $0.9 \%$ in Tris- $\mathrm{HCl} \mathrm{pH}$ 7.8 buffer. The mixture was placed in a tube and incubated at $30{ }^{\circ} \mathrm{C}$ for $24 \mathrm{~h}$. Soon after, $16 \mathrm{~mL}$ of acetone P.A. were added to stop the enzymatic reaction, leaving the homogenate in the dark for 2 hours. The soil suspension was then filtered and the absorbance of the filtrate evaluated at $546 \mathrm{~nm}$ in a spectrophotometer. A standard curve was constructed to quantify the amount of 2,3,5-triphenyl formazan of each sample (unit for TFP.ml ${ }^{-1}$ ) at $0,7,21,35,49$ and 60 th day of incubation.

\section{FUEL EXTRACTION FROM SOIL SAMPLES}

In order to verify the biodegradation percentages of the hydrocarbons and esters (B0, B20 and B100) present in respirometric flasks with $300 \mathrm{~g}$ of soil, two chromatographic analyses were conducted, the first at time zero and the second at the end of the experiment (60 days). Always before collection, the soil was turned over with a spatula to oxygenize and ensure mixture homogeneity. Subsequently, composite samples from five equidistant points within each flask were collected, and $5 \mathrm{~g}$ of soil was taken at each point, in order to complete $25 \mathrm{~g}$. Soil samples remained at $-18{ }^{\circ} \mathrm{C}$ until fuel extraction. Thereafter, the samples underwent a Soxhlet extraction process for 12 hours using methanol/dichloromethane grade pesticide (1:3) (V/V) as organic solvents (USEPA 1996). The extracted material was concentrated by rotary evaporator (RV 05 - ST IKA - WERKE) at $50 \mathrm{rpm}$. In turn, the amount of residual water in the sample was removed by adding anhydrous sodium sulphate. The extract was then washed with dichloromethane grade pesticide and transferred to a new vial. Subsequently, the extract remained evaporating in a fume hood until constant weight. The samples were stored at $-18{ }^{\circ} \mathrm{C}$ until submitted to chromatographic analysis.

\section{FUEL DEGRADATION}

The degradation of fuels of different treatments was evaluated by TPH (total petroleum hydrocarbon) measurements for B0 and B20 concentrations and total esters for B20 and B100 at the beginning (time zero) and at the end of the experiment (after 60 days of incubation). For pure diesel and the diesel fraction in $\mathrm{B} 20$, the hydrocarbon band between $\mathrm{C}_{8}$ $-\mathrm{C}_{28}$ was evaluated. The analyses were compared to the primary standard of the same fuel batches used in the biodegradation experiments. The calculation of the degradation percentage after 60 days of incubation was according to the formula:

(DTF - DTI) / DTI . 100

Equation 2

where DTF: fuel concentration at the final time (60 days), DTI: fuel concentration at time zero. For the determination of total esters was used a Dani GC 1000 Digital Pressure Control (DPC) chromatograph, FID detector, Linear Programmed Temperature Vaporizer injection (L-PTV), with temperature and pressure programming during a 1:15 split injection (L-PTV injector: $118{ }^{\circ} \mathrm{C} / 0.75$ min., aq $999{ }^{\circ} \mathrm{C} / \mathrm{min} .175{ }^{\circ} \mathrm{C} / 20 \mathrm{~min}$.) and a DBWax column (30 m x $0.32 \mathrm{~mm}$ x $0.25 \mathrm{um}$ ); an initial oven column temperature of $50{ }^{\circ} \mathrm{C} / 6$ min. and final temperature of $230{ }^{\circ} \mathrm{C}$ with rate of $5{ }^{\circ} \mathrm{C} / \mathrm{min}$.; $6 \mathrm{~min}$ retention time; detection temperature $260{ }^{\circ} \mathrm{C} ; \mathrm{N}_{2}$ gas flow at $10 \mathrm{~mL} / \mathrm{min}$. and run time of 50 min., according to ASTM D 6584 (2012) and EN 14110 (2003) methods. The Total Petroleum Hydrocarbons were determined 
by the USEPA 8015B (1996) method. Soil samples were extracted with hexane and dichloromethane in 1:1.5 proportion and an aliquot of the extract $(2 \mu \mathrm{L})$ was injected in a gas chromatograph (Dani GC1000) with flame ionization detector (FID) and capillary column VF-5MS (30 m x $0.53 \mathrm{~mm} \times 1.5$ $\mu \mathrm{m})$. Nitrogen was employed as carrier gas and the hydrocarbon concentration was quantified using external standardization. The method detection limit was $0.05 \mathrm{mg} \cdot \mathrm{kg}^{-1}$.

\section{COUNTING OF TOTAL HETEROTROPHIC \\ BACTERIA AND FUEL DEGRADER BACTERIAL COMMUNITY}

Total heterotrophic bacteria's counting was measured using $1 \mathrm{~g}$ of soil sample from each respirometric flask, submitted to serial dilutions $\left(10^{-1}\right.$ to $\left.10^{-9}\right) \cdot 100 \mu \mathrm{L}$ of each serial dilution +100 $\mu \mathrm{L}$ of TSB broth (Himedia) were added to 96 well plates, wrapped in aluminium foil and incubated at $28{ }^{\circ} \mathrm{C}$ for $48 \mathrm{~h}$. Colony forming units (CFU) were measured by medium turbidity, according to FDA (2001), and represented by CFU.g ${ }^{-1}$ dry soil. Fuel degraders counting was measured by 2,3,5-triphenyl tetrazolium chloride (TTC) redox indicator. The soil samples were also performed as described above. $100 \mathrm{uL}$ of each serial dilution $+100 \mu \mathrm{L}$ of basal mineral medium MM1 with TTC (Braddock and Catterall 1999) $+10 \mu \mathrm{L}$ of B50 (diesel:biodiesel) were added to 96 well plates, wrapped in aluminium foil and incubated at $28{ }^{\circ} \mathrm{C}$ for $10-14$ days. This technique looks for microorganisms capable to use B50 as a carbon source, detected by redox indicator (2,3,5-triphenyl tetrazolium chloride reduced to 2,3,5- triphenyl tetrazolium formazan, with colorless solution turned to rose color). CFU was also measured as described above.

\section{STATISTIC ANALYSIS}

The obtained results were analyzed by the Tukey test (comparison between mean values) and
ANOVA, for a confidence level of $95 \%$ using the Sisvar program, version 4.6, (Build 60) (Ferreira 2011). The graphics were performed by SigmaPlot software, version 12.5.

\section{RESULTS}

The principal physicochemical attributes of a type of ultisol used to make up the microcosm are detailed in Table I.

When the cumulative $\mathrm{CO}_{2}$ production after 60 days of incubation was evaluated, it was observed that all the analyzed results presented respiratory activity levels above their respective negative controls (no fuel). If considering the cumulative $\mathrm{CO}_{2}$ production levels for different diesel/biodiesel (B0, B20 and B100) mixtures, it can be seen that, under natural attenuation, there was no increase in the $\mathrm{CO}_{2}$ release rate as the biodiesel concentration was

TABLE I

Physicochemical attributes of ultisol evaluated.

\begin{tabular}{|c|c|}
\hline Atribute & $\begin{array}{c}\text { Depth (0- } 20 \\
\text { cm) }\end{array}$ \\
\hline Organic Matter $\left(\mathrm{g} \mathrm{Kg}^{-1}\right)$ & 11 \\
\hline Clay $(\%)$ & 9 \\
\hline Fine Sand $(\%)$ & 41 \\
\hline Coarse Sand $(\%)$ & 42 \\
\hline Silt (\%) & 8 \\
\hline Organic Carbon $\left(\mathrm{g} \mathrm{Kg}^{-1}\right)$ & 5 \\
\hline Total Nitrogen $\left(\mathrm{g} \mathrm{Kg}^{-1}\right)$ & 0.5 \\
\hline Available $\mathrm{P}\left(\mathrm{mg} \mathrm{dm}^{-3}\right)$ & 0 \\
\hline Available $\mathrm{K}\left(\mathrm{mg} \mathrm{dm}^{-3}\right)$ & 68 \\
\hline Effective CEC $\left(\mathrm{mmol}_{\mathrm{c}} \mathrm{dm}^{-3}\right)^{1}$ & 2.3 \\
\hline CEC pH $7\left(\mathrm{mmol}_{\mathrm{c}} \mathrm{dm}^{-3}\right)^{2}$ & 5.4 \\
\hline $\mathrm{Al}\left(\mathrm{mmol}_{\mathrm{c}} \mathrm{dm}^{-3}\right)$ & 0.8 \\
\hline $\mathrm{Ca}\left(\mathrm{mmol}_{\mathrm{c}} \mathrm{dm}^{-3}\right)$ & 0.9 \\
\hline $\operatorname{Mg}\left(\mathrm{mmol}_{\mathrm{c}} \mathrm{dm}^{-3}\right)$ & 0.4 \\
\hline $\mathrm{H}+\mathrm{Al}\left(\mathrm{mmol}_{\mathrm{c}} \mathrm{dm}^{-3}\right)$ & 3.9 \\
\hline $\mathrm{pH}\left(\mathrm{H}_{2} \mathrm{O}\right)$ & 4.8 \\
\hline SMP Index & 6.1 \\
\hline
\end{tabular}


increased in the diesel/biodiesel mixture (Figure 1). However, for the bioaugmentation/biostimulation strategy, there are microbial activity differences among fuel mixtures in the soil (B100> B20> B0> NC) (Figure 1). It was also observed that there was higher respiratory activity for fuel types (B100, B20 and B0) when subjected to bioaugmentation/ biostimulation, compared to natural attenuation.

The results of the dehydrogenase group enzymatic activities are summarized in Figure 2. For the natural attenuation strategy, in general, a decreasing dehydrogenase activity trend was observed over 60 days of incubation, with higher enzyme activity verified at the first two monitoring points (at 0 and 7 days of incubation). On the other hand, for bioaugmentation/biostimulation strategy, generally the significant enzyme values occur for the last two monitoring points (49 and 60 days of incubation), besides the B20 treatment at 21 days. It may be explained by an initial adaptation phase for microbial community added to the microcosms, when it enjoys the nutrients $(\mathrm{N}, \mathrm{P}, \mathrm{K})$ provided to degrade simple carbon source from microcosm. After this period, the fuel carbon source degradation starts. In addition, for both bioremediation strategies, monitoring points that showed highest enzyme activity were in the B100 treatments.

The results of the degrading and heterotrophic microorganism counts obtained by the two bioremediation strategies in an ultisol are summarized in Figure 3. In most treatments, there was no significant increase in the population growth rate during the 60 days of incubation, although major differences were observed between heterotrophic and degrading microorganism counts for the bioaugmentation/biostimulation strategy, compared to the natural attenuation. For both bioremediation strategies, there was a reduction of degrading microorganism counts from the $35^{\text {th }}$ day of incubation. In the natural attenuation, this

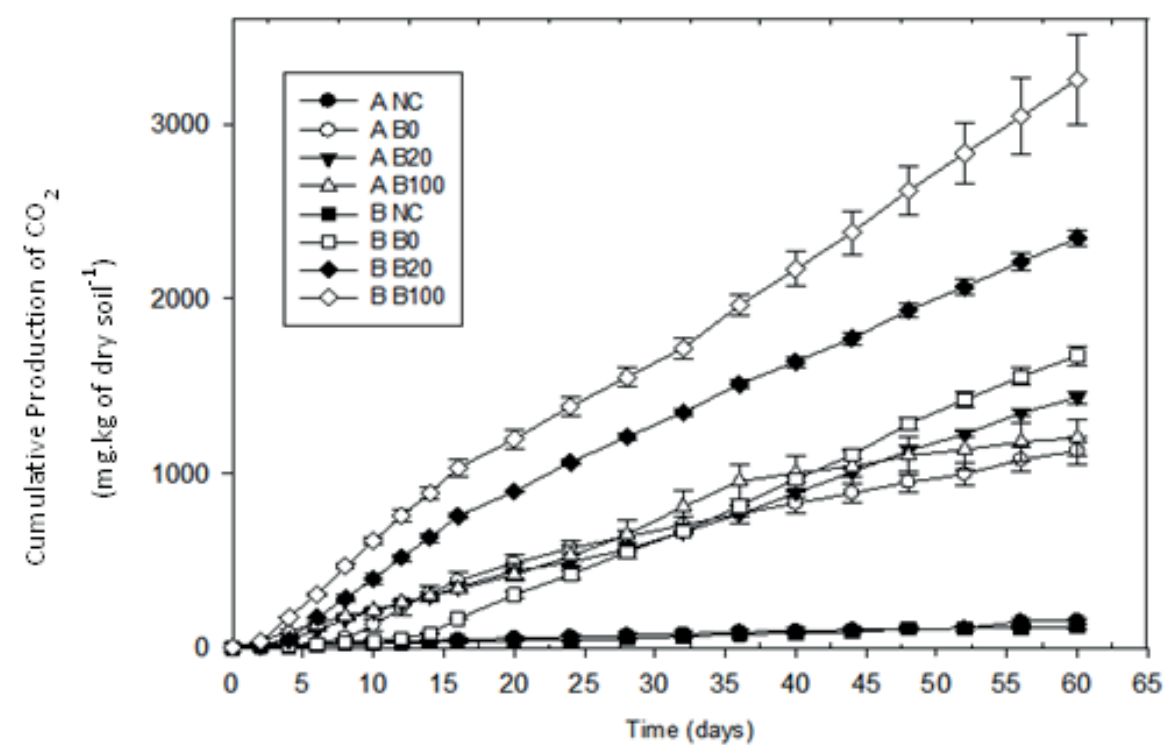

Figure 1 - Cumulative $\mathrm{CO}_{2}$ production from an ultisol contaminated by different diesel/ biodiesel mixtures (B0, B20 and B100) in two bioremediation strategies: natural attenuation (A) and bioaugmentation/biostimulation (B) during 60 days of incubation. A NC (A: natural attenuation, $\mathrm{NC}$ : control treatment without contamination). B NC (B: bioaugmentation/ biostimulation, $\mathrm{NC}$ : control treatment without contamination). B0: pure diesel; B20: 20\% biodiesel added to diesel; B100: pure biodiesel. 
occurred for the B100 treatment, while the B0 and B20 treatments maintained a population rate of $10^{7}$ CFU.g ${ }^{-1}$ soil by the end of incubation. As for the bioaugmentation/biostimulation, the B0 and B20 were the treatments that had their population reduced from $35^{\text {th }}$ day of incubation, and the B100 was the treatment in which the population remained at $10^{6}-10^{7} \mathrm{CFU} \cdot \mathrm{g}^{-1}$ soil until the end of incubation.

The results of hydrocarbon and ester degradation after 60 days of incubation can be seen in Table II. The degradation percentage was calculated by the difference in concentration of hydrocarbons and/or esters detectable by gas chromatography from time zero, in relation to time 60 (days of incubation). For evaluating the diesel degradation, the concentration of TPH (Total Petroleum Hydrocarbon) in the soil was estimated by considering only the light fraction $\left(\mathrm{C}_{8}-\mathrm{C}_{28}\right)$ made up of a large proportion of aliphatic hydrocarbons and, to a lesser extent, aromatics. For the biodiesel fraction, the parameter used to evaluate the degradation was the detection of total esters. There was degradation for both bioremediation strategies. B0 and B20 treatments showed degradation rates about $90 \%$, although there were significant differences in the degradation of the two diesel/ biodiesel mixtures through adding the bacterial consortium and nutrients. Indeed, B100 was the only fuel in the soil that showed statistically significant differences between bioremediation strategies. The addition of bacterial inoculum plus nutrients contributed to its biodegradability (degradation rate of 59.77 and $74.53 \%$ for B100, respectively, under natural attenuation and bioaugmentation/ biostimulation).

Treatments for both bioremediation strategies were: $\mathrm{B} 100>\mathrm{B} 20>\mathrm{B} 0$ for dehydrogenase enzyme activity as well as for $\mathrm{CO}_{2}$ production. Furthermore, the microbial activity was higher for the bioaugmentation/biostimulation in relation to natural attenuation for diesel/biodiesel mixtures (B0, B20 and B100). For the biodegradation results, the $\mathrm{B} 0$ and $\mathrm{B} 20$ treatments had highest percentages, not presenting, however, statistic differences between the two bioremediation strategies. On the other hand, although B100 had presented a lower degradation percentage compared with B0 and B20 treatments, the addition of the bacterial consortium and nutrients contributed to an increase in the B100 treatment degradation percentage, compared to the same treatment under natural attenuation.

\section{DISCUSSION}

Many studies have demonstrated the success of natural attenuation in which the biodegradation of hydrocarbons can be efficient, mainly regarding the presence of bacteria and indigenous fungi (Bento et al. 2005, Sarkar et al. 2005, Margesin et al. 2007, Di Toro et al. 2008). This fact also occurred in B0 as well as in B20 mixture, since these two treatments showed no degradability differences when bacterial consortium and nutrients were added to the system. However, it is important to consider that the B0 treatment, even with decrease in the size of the degrading population from incubation in day 35 , showed high degradation of the light diesel fraction (96.5\%) (Figure 2 and Figure 3; Table II). On the other hand, the counting of degrading populations remained high and constant until the end of incubation for treatments A B0 and A B20, related to natural attenuation strategy (Figure 3 ). This shows that these populations probably exhibited favorable metabolic and genetic support, even under natural conditions to degrade hydrocarbons. It means that these bacteria would present specific enzymatic display for biodegradation of fuel contaminants. In general, for the natural attenuation strategy, high B20 and $\mathrm{B} 0$ treatment degradation rates were achieved, corresponding to a percent over 90 (Table II).

The B100 treatment showed less degradation when compared to the B0 and B20 mixtures for both bioremediation strategies. On the other hand, the B100 treatment showed highest degradation 
TABLE II

Comparison of three different methods to assess microbial activity and biodegradation: dehydrogenase activity, cumulative $\mathrm{CO}_{2}$ production and degradation percentage of the diesel/biodiesel (B0, B20 and B100) mixtures after 60 days, for the two bioremediation strategies [natural attenuation (A) and bioaugmentation/biostimulation (B)] in an ultisol.

\begin{tabular}{|c|c|c|c|c|c|c|}
\hline \multirow[t]{2}{*}{ Treatment } & \multicolumn{2}{|c|}{ Dehydrogenase $^{1}$} & \multicolumn{2}{|c|}{$\begin{array}{c}\text { Cumulative } \mathrm{CO}_{2} \text { Production } \\
\left(\mathrm{mg}^{-\mathrm{Kg}^{-1}} \text { dry soil) (60 days) }\right.\end{array}$} & \multicolumn{2}{|c|}{$\begin{array}{c}\text { Biodegradation Percentage } \\
(\%)\end{array}$} \\
\hline & A & B & A & $\mathrm{B}$ & A & $\mathrm{B}$ \\
\hline $\mathrm{NC}$ & $7.04 \mathrm{Ab}^{*}$ & $6.89 \mathrm{Ab}$ & 154.44 Ac & 119.89 Ad & $\mathrm{ND}^{2}$ & ND \\
\hline B0 & 10.31Aab & $5.31 \mathrm{Ab}$ & $1126.42 \mathrm{Bb}$ & $1674.02 \mathrm{Ac}$ & $96.47 \mathrm{Aa}$ & $98.15 \mathrm{Aa}$ \\
\hline $\mathrm{B} 20$ & 15.00 Bab & $21.27 \mathrm{Aa}$ & 1202.91 Bab & $2347.41 \mathrm{Ab}$ & $90.56 \mathrm{Aa}$ & $84.65 \mathrm{Aa}$ \\
\hline $\mathrm{B} 100$ & $18.07 \mathrm{Aa}$ & $23.90 \mathrm{Aa}$ & $1433.77 \mathrm{Ba}$ & $3255.73 \mathrm{Aa}$ & $59.77 \mathrm{Ab}$ & $74.53 \mathrm{Aa}$ \\
\hline
\end{tabular}

*Averages followed by the same upper case in the lines, and lower case in the columns, do not present statistic difference from each other, according to Tukey test with $5 \%$ probability; ${ }^{1}$ average of the 6 monitoring points during the 60 days of incubation; ${ }^{2} \mathrm{TPH}$ values not detected in the soil (ND).

percentages for bioaugmentation/biostimulation, compared to the natural attenuation. It was also observed that for B B100 treatment, the degrading microorganism counts showed constant $\left(10^{7}\right.$ CFU.g ${ }^{-1}$ dry soil) to the end of the experiment during 60 days, besides presenting an increase of dehydrogenase activity at the last two monitoring points for that same treatment (Figure 2). Comparing the same mixture for natural attenuation, it is observed that the degrading microorganisms rates fell from the 35th day of incubation, reaching values close to $10^{4}$ CFU.g ${ }^{-1}$ dry soil. Additionally, this same treatment showed a similar reduction profile for the dehydrogenase activity from 21 days of incubation. These data confirm that the B100 treatment for the bioaugmentation/biostimulation strategy was more promising, compared to the natural attenuation, reinforcing the concept that the bacterial consortium may have retained their potential for resilience throughout the incubation period, favoring the increasing in degradability of the mixture, as shown in Table II. Furthermore, the addition of nutrients to the system may have favored the maintaining of microbial populations at high levels for B100. The population decrease for the same treatment under natural attenuation was probably due to the lack of nutrients available in the microcosm from that particular incubation period, associated with the absence of the bacterial consortium addition to the system. According to Fantroussi and Agathos (2005), the combination of bioaugmentation with biostimulation should prove to be a promising strategy, since the exogenous microorganisms, as well indigenous, can benefit from the addition of nutrients to the system. However, in the present study, it is interesting to note that the treatments containing B100, while showing a low breakdown percentage, were those which also demonstrated high enzyme activity and cumulative $\mathrm{CO}_{2}$ production values. The release of $\mathrm{CO}_{2}$ in soils is an indirect way to estimate the decarboxylation of organic compounds that are degraded in the system (Margesin et al. 2000). Moreover, a large dehydrogenases group participates in processes related to the assimilation and degradation of organic compounds by the citric acid cycle (Schinner et al. 1996, Margesin et al. 2000). These data also help confirm the higher degradation rate of treatment B B100 in relation to the A B100 (Table II).

The main criterion for choosing the bacterial consortium for the bioaugmentation strategy was determined from the optimum results for biodegradability for each isolate. Thus, evaluation of various enzyme activities in addition to the estimated production of high and low molecular 


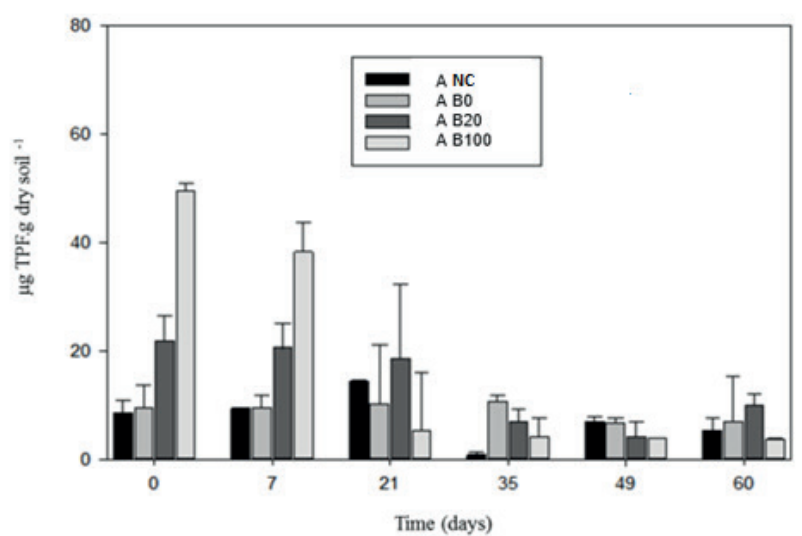

A. Natural Attenuation

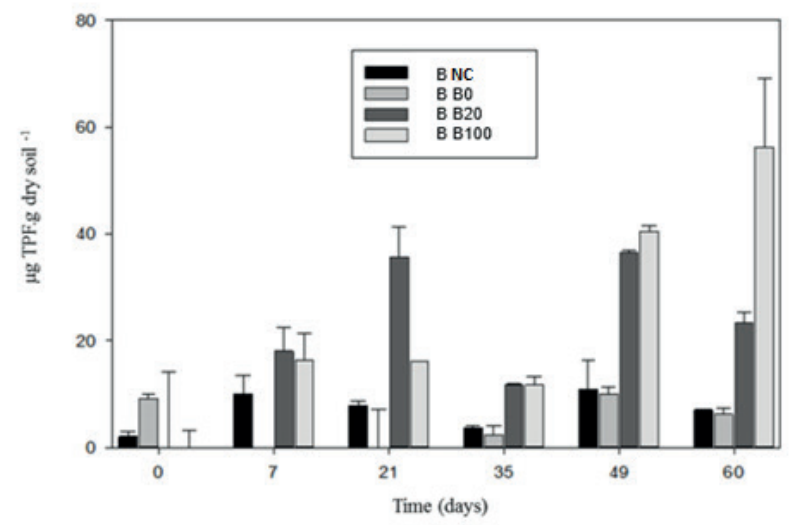

B. Bioaugmentation/Biostimulation

Figure 2 - Dehydrogenase activity in an ultisol contaminated with different fuel types (B0, B20 and B100) in two bioremediation strategies: natural attenuation (A) and bioaugmentation/biostimulation (B) during 60 days of incubation. A NC (A: natural attenuation, NC: control treatment without contamination). B NC (B: bioaugmentation/biostimulation, NC: control treatment without contamination). B0: pure diesel; B20: 20\% biodiesel added to diesel; B100: pure biodiesel.

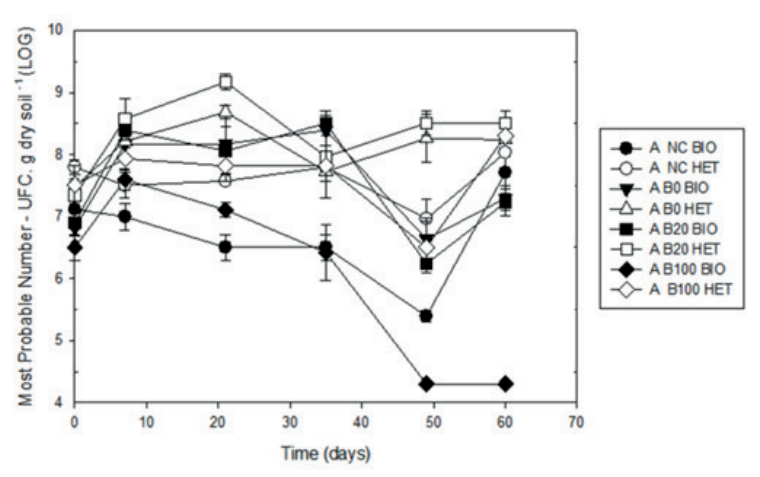

A. Natural Attenuation

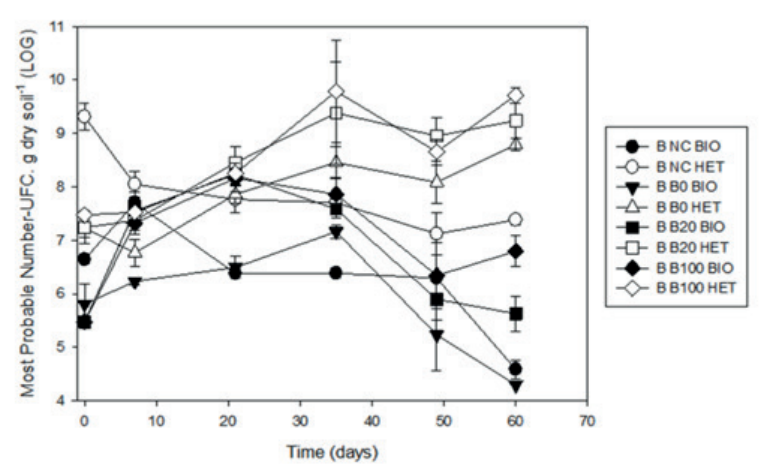

B. Bioaugmentation/Biostimulation

Figure 3 - Comparison of degrading (BIO) and heterotrophic (HET) microorganism counts in an ultisol contaminated by different mixtures of diesel/biodiesel (B0, B20 and B100) in two bioremediation strategies: natural attenuation (A) and bioaugmentation/ biostimulation (B) during 60 days of incubation. A NC (A: natural attenuation, NC: control treatment without contamination). B NC (B: bioaugmentation/biostimulation, NC: control treatment without contamination). B0: pure diesel; B20: 20\% biodiesel added to diesel; B100: pure biodiesel.

weight biosurfactants, associated with cell growth, were positive tools in order to elect four potentially degrading bacteria for the $\mathrm{B} 0, \mathrm{~B} 20$ and $\mathrm{B} 100$ mixtures, all isolated from a landfarming cell located in a petrochemical industry in southern Brazil. Thus, according to the partial sequencing of the $16 \mathrm{~S}$ region of ribosomal RNA, it was possible to identify the following isolates: Bacillus megaterium 1, Bacillus pumilus 2, Pseudomonas aeruginosa 5 and Stenotrophomonas maltophilia 6 (Meyer et al. 2012). It was found that these genera selected for the degrading consortium showed an intense relationship with the biodegradation processes of the fractions present in the diesel/biodiesel mixtures, according to the literature data published in the last decades (Atlas 1981, Leahy and Colwell 1990, Jacques et al. 2005, 2007, Chao et al. 2010, Thavasi et al. 2011, Maddela et al. 2016).

The bioaugmentation has no obvious limitations as to microbial degradation. However, this strategy may present flaws (Thompson et al. 2005). Considering the microbial ecology, 
the selection of strains comes based on one key criterion in order to enable microorganisms to degrade, without regard to the potential of these strains in actively proliferating in different places where they were applied. Thus, as shown in some studies, the bioaugmentation with exogenous microorganisms usually ends up being effective only in the first days of incubation, due to the difficult task of adapting to the physical, chemical and biological characteristics of soil (Schwartz and Scow 2001, Bento et al. 2005, McKew et al. 2007).

Despite the inefficiency that exogenous microbial consortia may generate in relation to the degradation of diesel/biodiesel mixtures, since strains isolated from a soil can not necessarily be applied on another contaminated site because of the great complexity of these systems (Hosokawa et al. 2009), one should consider the possibility of investing in microbial consortia banks with degrading potential. This alternative may increase the chances of degradation success in areas contaminated by fuel, since the time required for the isolation and enrichment of microorganisms that are reintroduced in the impacted same location (autochthonous) is not always feasible in practice.

Thus, when organizing a database with detailed records of the physical, chemical and biological properties of impacted soil in which they were obtained, the chances of choosing a consortium or a bacterial strains mix compatible with the soil of interest to be decontaminated may be higher. Adding the inoculum several times throughout the incubation instead of a single application at the beginning can also contribute to the success of the exogenous population category and, therefore, increasing degradation of diesel/biodiesel mixtures in the soil, avoiding abrupt drops in population structure, caused mainly by competition from indigenous microorganisms and predation by protozoa (Schwartz and Scow 2001).

\section{CONCLUSIONS}

The goal of bioremediation was achieved in an ultisol submitted to surface contamination by B0, B20 and B100. Natural attenuation showed high biodegradation rates for the B0 and B20 mixtures, whereas the previously selected bacterial consortium, combined with the addition of nutrients, was effective to accelerate the biodegradation of pure biodiesel (B100). From the degrading counting and dehydrogenase activity, it was possible to suggest that the inoculated bacterial consortium may have remained in the system along the incubation period, contributing to greater B100 biodegradability.

\section{ACKNOWLEDGMENTS}

The authors acknowledge Conselho Nacional de Desenvolvimento Científico e Tecnológico (CNPq) for a M.Sc. Scholarship. This work was supported with resources from Laboratório de Biodeterioração de Combustíveis e Biocombustíveis (LAB-BIO) of the Federal University of Rio Grande do Sul, Brazil.

\section{REFERENCES}

ALEF K. 1995. Dehydrogenase activity. In: Alef K and Nannipieri P (Eds), Methods in Applied Soil Microbiology and Biochemistry. London: Academic Press, 576 p.

ASTM D 6584. 2012. Standard test method for determination of total monoglycerides, total diglycerides, total triglycerides and free and total glycerin in B100 biodiesel methyl ester by gas chromatography. Available at: http://www.astm. org/Standards/D6584.html. (Accessed on April 6, 2017).

ATLAS RM. 1981. Microbial degradation of petroleum hydrocarbons: an environmental perspective. Microbiol Rev 45: 180-209.

BENTO FM, CAMARGO FAO, OKEKE B AND FRANKENBERGER-JÚNIOR WT. 2003. Bioremediation of soil contaminated by diesel oil. Braz J Microbiol 34: 6568.

BENTO FM, CAMARGO FAO, OKEKE B AND FRANKENBERGER WT. 2005. Comparative bioremediation of soils contaminated with diesel oil by natural Attenuation, biostimulation and bioaugmentation. Bioresource Technol 96: 1049-1055. 
BRADDOCK JF AND CATTERALL PH. 1999. A Simple Method for Enumerating Gasoline- and Diesel-Degrading Microorganisms. Bioremediat J 3: 81-84.

BRASIL. 2016. Lei $n^{\circ} 13.263$, de 23 de março de 2016. Altera a Lei $n^{0} 13.033$, de 24 de setembro de 2014, para dispor sobre os percentuais de adição de biodiesel ao óleo diesel comercializado no território nacional. Disponível em: http://www2.camara.leg.br/legin/fed/lei/2016/lei-1326323-marco-2016-782625-publicacaooriginal-149818-pl. html. (Acceso em 8 de Maio, 2017).

CHAO Y, LIU N, ZHANG T AND CHEN S. 2010. Isolation and characterization of bacteria from Engine sludge generated from biodiesel-diesel blends. Fuel 89: 33583364.

DI TORO S, ZANAROLI G, VARESE GC, MARCHISIO VP AND FAVA F. 2008. Role of enzyveba in the aerobic bioremediation and detoxification of a soil freshly contaminated by two different diesel fuels. Int Biodeter Biodegr 62: 153-161.

EMBRAPA. 2006. Centro Nacional de Pesquisa de Solos. Sistema de Classificação de Solos, $2^{a}$ ed., Brasília: EMBRAPA, 306 p.

EN 14110. 2003. Fat and Oil Derivatives Fatty Acid Methyl Esters (FAME), Determination of Methanol Content. Available at: https://www.en-standard.eu/ilnasen-14110-fat-and-oil-derivatives-fatty-acid-methylesters-fame-determination-of-methanol-content-1/?gc lid=CjwKCAjwkYDbBRB6EiwAR0T -tZ31OBTHFRMVOUYgE 18 D pq 8 h s AfjeZHdr6OKIw C t9syC9V54H_7BoCicwQAvD_BwE. (Accessed on July $31,2018)$

FANTROUSSI S AND AGATHOS SN. 2005. Is bioaugmentation a feasible strategy for pollutant removal and site remediation? Curr Opin Microbiol 8: 268-275.

FDA - FOOD AND DRUG ADMINISTRATION. 2001. Bacteriological Manual Online. Available at: http:/www. cfsan.fda.gov. (Accessed on June 6, 2009).

FERNANDEZ-ALVAREZ P, VILA J, GARRIDO JM, GRIFOLL M, FEIJOO G AND LEMA JM. 2007. Evaluation of biodiesel as bioremediation agent for the treatment of the shore affected by the heavy oil spill of the Prestige. J Hazard Mater 147: 914-922.

FERREIRA DF. 2011. Sisvar: a computer statistical analysis system. Cien Agrotec 35: 1039-1042.

GONG Z, WANG X, TU Y, WU J, SUN Y AND LI P. 2010. Polycyclic aromatic hydrocarbon removal from contaminated soils using fatty acid methyl esters. Chemosphere 79: 138-143.

HOSOKAWA R, NAGAI M, MORIKAWA M AND OKUYAMA H. 2009. Autochthonous bioaugmentation and its possible application to oil spills. World J Microb Biot 25: 1519-1528.
JACQUES RJS, BENTO FM, ANTONIOLLI ZI AND CAMARGO FAO. 2007. Biorremediação de solos contaminados com hidrocarbonetos aromáticos policíclicos. Cienc Rural 37: 1192-1201.

JACQUES RJS, SANTOS EC, BENTO FM, PERALBA MCR, SELBACH PA, SÁ ELS AND CAMARGO FAO. 2005. Anthracene biodegradation by Pseudomonas sp. isolated from a petrochemical sludge landfarming site. Int Biodeter Biodegr 56: 143-150.

JIMÉNEZ N, VIÑAS M, BAYONA JM, ALBAIGES J AND SOLANAS AM. 2007. The Prestige oil spill: bacterial community dynamics during a field biostimulation assay. Appl Microbiol Biot 77: 935-945.

KNOTHE G. 2010. Biodiesel and renewable diesel: a comparison. Prog Energ Combust 36: 364-373.

LEAHY JG AND COLWELL RR. 1990. Microbial degradation of hydrocarbons in the environment. Microbiol Rev 54: 305-315.

LIU PG, WHANG L, CHANG TC, TSENG I, PAN P AND SHENG-SHUNG CHENG S. 2009. Verification of necessity for bioaugmentation - lessons from two batch case studies for bioremediation of diesel-contaminated soils. J Chem Technol Biot 84: 808-819.

MADDELA NR, BURGOS R, KADIYALA V, CARRION AR AND BANGEPPAGARI M. 2016. Removal of petroleum hydrocarbons from crude oil in solid and slurry phase by mixed soil microorganisms isolated from Ecuadorian oil fields. Int Biodeter Biodegr 108: 85-90.

MARGESIN R, HAMMERLE M AND TSCHERKO D. 2007. Microbial activity and community composition during bioremediation of diesel-oil-contaminated soil: effects of hydrocarbon concentration, fertilizers and incubation time. Microbial Ecol 53: 259-269.

MARGESIN R, ZIMMERBAUER A AND SCHINNER F. 2000. Monitoring of bioremediation by soil biological activities. Chemosphere 40: 339-346.

MCKEW BA, COULON F, YAKIMOV MM, DENARO R, GENOVESE M, SMITH CJ, OSBOM AM, TIMMIS KN AND MCGENITY TJ. 2007. Efficacy of intervention strategies for Bioremediation of crude oil in marine systems and effects on indigenous hydrocarbonoclastic bacteria. Environ Microbiol 9: 1562-1571.

MEYER DD, BEKER SA, BÜCKER F, PERALBA MCR, FRAZZON APG, OSTI JF, ANDREAZZA R, CAMARGO FAO AND BENTO FM. 2014. Bioremediation strategies for diesel and biodiesel in oxisol from southern Brazil. Int Biodeter Biodegr 95: 356-363.

MEYER DD, SANTESTEVAN NA, BÜCKER F, SALAMONI SP, ANDREAZZA R, CAMARGO FAO AND BENTO FM. 2012. Capability of a selected bacterial consortium for degrading diesel/biodiesel blends (B20): Enzyme and biosurfactants production. J Environ Sci Heal A 47: 17761784. 
SARKAR D, FERGUSON M, DATA R AND BIRNBAUM S. 2005. Bioremediation of petroleum hydrocarbons in contaminated soils: comparison of biosolids addition, carbon supplementation and monitored natural attenuation. Environ Pollut 136: 187-195.

SCHINNER F, ÖHLINGER R, KANDELER E AND MARGESIN R. 1996. Methods in Soil Biology. Berlin: Springer-Verlag, $418 \mathrm{p}$.

SCHWARTZ E AND SCOW KM. 2001. Repeated inoculation as a strategy for the remediation of low concentrations of phenanthrene in soil. Biodegradation 12: 201-207.

SILVA GS, MARQUESA ELS, DIASA JCT, LOBO IP, GROSS E, BRENDELA M, CRUZ RS AND REZENDE RP. 2012. Biodegradability of soy biodiesel in microcosm experiments using soil from the Atlantic Rain Forest. Appl Soil Ecol 55: 27-35.

STOTZKY G. 1965. Microbial Respiration. In: Black CA, Evans DD, Ensnunger LE, Vaute JL and Clark FE (Eds), Methods in soil analysis: chemical and microbiological properties. Madison: American Society of Agronomy, p. 1550-1572.

TAHHAN RA, AMMARI TG, GOUSSOUS SJ AND ALSHDAIFAT HI. 2011. Enhancing the biodegradation of total petroleum hydrocarbons in oily sludge by a modified bioaugmentation strategy. Int Biodeter Biodegr 65: 130134.

TEDESCO MJ, GIANELLO C, BISSANI CA, BOHNEN H AND VOLKWEISS SJ. 1995. Análise de solo, plantas e outros materiais, $2^{\text {a }}$ ed., Porto Alegre, Universidade Federal do Rio Grande do Sul, 174 p.

THALMANN A. 1968. Zur methodik der bestimmung der dehidrogenase aktivita triphenyltetrazolium chlorid (Ttc) im bodem mittels. Lanawiktsch Forsch 21: 249-258.

THAVASI R, JAYALAKSHMI S AND BANAT IM. 2011. Effect of biosurfactant and fertilizer on biodegradation of crude oil by marine isolates of Bacillus megaterium, Corynebacterium kutscheri and Pseudomonas aeruginosa. Bioresource Technol 102: 772-778.

THOMPSON IP, VAN DER GAST CJ, CIRIC L AND SINGER AC. 2005. Bioaugmentation for bioremediation: the challenge of strain selection. Environ Microbiol 7: 909-915.

TYAGI M, FONSECA MMR AND CARVALHO CCCR. 2011. Bioaugmentation and biostimulation strategies to improve the effectiveness of bioremediation processes. Biodegradation 22: 231-241.

USEPA 8015B. 1996. Nonhalogenated organics using GC/ Fid. Available at: http://www.caslab.com/EPAMethods/ PDF/8015b.pdf. (Accessed on February 12, 2017).

XU Y AND LU M. 2010. Bioremediation of crude oilcontaminated soil: comparison of different biostimulation and bioaugmentation treatments. J Hazard Mater 183: 395-401.

YASSINE MH, WU S, SUIDAN MT AND VENOSA AD. 2013. Aerobic biodegradation kinetics and mineralization of six petrodiesel/soybean-biodiesel blends. Environ Sci Technol 4: 4619-4627. 